\title{
Veiled Muslim women's views on law banning the wearing of the niqab (face veil) in public
}

Irene Zempi ${ }^{1}$

Department of Sociology, Nottingham Trent University, Nottingham, UK

\section{ABSTRACT}

In August 2018, Denmark became the latest European country to ban the wearing of the niqab (face veil) in public. Indeed, several European countries such as France, Belgium and Austria have already imposed a national ban on the wearing of the niqab in public on the grounds that it is a 'threat' to gender equality, integration and national security. While the wearing of the niqab has elicited a good deal of media, political and public debates, little attention has been paid to the opinions of Muslim women who wear it. Drawing on individual and focus group interviews with Muslim women who wear the niqab in the United Kingdom (UK), this article places at the centre of the debate the voices of those women who do wear it and, under the lens of Critical Race Feminism, explores their views on legislation banning the wearing of the niqab in public.

ARTICLE HISTORY Received 08 August 2018; Accepted 20 December 2018

\section{KEYWORDS}

Critical Race Feminism, Islamophobia, Muslim Women, Niqab, Veil Ban

\section{Introduction}

In a post-9/11 climate, several European countries have enforced legislation, which makes it illegal for Muslim women to wear the niqab in public. In 2011 France became the first country in Europe to introduce a law (Act No 20101192 of 11 October 2010) prohibiting the concealing of the face in public, and then other countries such as Belgium and Austria followed suit. Denmark is the latest European country to ban the wearing of the niqab in public places. The Netherlands has a partial ban on the niqab as it is not accepted in education and healthcare institutions, government buildings and on public transport. Justifications in favour of the veil ban generally take three forms: the wearing of the niqab a) is incompatible with Western values including gender equality; b) impedes communication and integration; and c) poses a security risk.

${ }^{1}$ Irene Zempi: Email irene.zempi@ntu.ac.uk, Twitter @DrIrene.Zempi 
However, the exclusion of veiled Muslim women from media, political and public debates is striking. As Droogsma (2007) points out, essentialist images of veiled Muslim women portrayed in the media fail to incorporate women's voices. Brems (2011) observes that the veil ban is based on outsider experiences and views. Legislators have shown little (if any) interest in learning about the views and experiences of veiled Muslim women regarding banning the wearing of the niqab in public (Brems 2015). Against this background, the present paper offers a timely opportunity to review the assumptions of the veil ban in countries where it is implemented, and inform policy making with respect to potentially banning the niqab in other countries where it is still legal to wear it such as the UK.

Drawing from qualitative data elicited through a UK-based study, this article sheds light on the lived experiences of veiled Muslim women and explores their views on legislation banning the wearing of the niqab in public. First, the article provides an overview of legislation banning the wearing of the niqab in those countries where it has been implemented. Secondly, the article outlines the theoretical framework used to analyse the research data namely Critical Race Feminism and examines previous research on this topic. Thirdly, the article explores veiled Muslim women's views on legislation banning the wearing of the niqab in public. At the time of conducting this research, France and Belgium were the only European countries to have implemented a law banning the wearing of the niqab in public; therefore, interviews with participants focused on the veil ban in these two countries. The article uses participants' quotations in order to illustrate the themes emerging from the analysis, offer readers greater depth of understanding and empower the study population by giving 'voice' to their issues. Within the framework of Critical Race Feminism, the paper helps to understand the views and experiences of veiled Muslim women by allowing the opportunity to hear their 'voices' in their own words.

\section{Setting the scene}

In a post-9/11 climate, the debate over the wearing of the niqab has become more prominent. In this period of time, wearing the niqab in public has become criminalised in certain European countries such as France, Belgium, Austria and Denmark whilst partial bans having been implemented in other countries such as the Netherlands, Italy and Spain.

Specifically, the law prohibiting the covering of faces in public spaces was approved by the French parliament in 2010, and came into effect on 11 April 2011. In practice, the law makes it illegal to appear in public with one's face fully covered, and anyone doing so is subject to a fine of 150 euros and/or required to complete a citizenship course. In theory, the law is intended to protect women's freedom and dignity, affirm gender equality and ensure

${ }^{1}$ Irene Zempi: Email irene.zempi@ntu.ac.uk, Twitter @DrIrene.Zempi 
public safety but in practice, the law targets Islam and veiled Muslim women as 'criminals'. However, targeting Islamic signs is not new to the French context. On 15 March 2004, the law banning the wearing of conspicuous religious signs was passed in France. In theory, the law seemed to include all religious signs, but in practice it was applied to Muslim girls wearing the hijab (Al-Saji 2010). Pro-law proponents interpreted this ban as a sign of France's rigorous secularism and French national identity (to which secularism was posited as central) as well as commitment to gender equality; however, opponents saw it as a symptom of France's colonial and racist history (Delphy 2004). According to Al-Saji (2010), the 2004 French law was a mechanism to exclude veiled Muslim women from the public space of schools and hence a way of rendering their agency 'invisible'. The 2010 law banning the niqab can be understood as an extension of this logic (Al-Saji 2010). In 2016, France introduced a controversial ban on women's full-body swimsuits, known as 'burkinis'. Prime Minister Manuel Valls called the swimsuits "the affirmation of political Islam in the public space" (Chrisafis 2016). The burkini ban, imposed by French Riviera mayors, was later lifted in seaside resorts after France's highest administrative court overruled the law on Friday 26 August 2016.

Grillo and Shah (2012) point out that while national in origin, policies to ban the niqab are usually followed by other countries. Indeed, Belgium was the second European country after France "to institute a prohibition against wearing clothing that covers the face or a large part of it" (Act of June 12011 ). According to Belgian Criminal Code, the Article punishes persons "who appear in places accessible to the public with their faces covered or concealed, in whole or in part, in such a manner that they are not recognisable" with a monetary fine of 15 to 25 euros and/or a prison sentence of one to seven days. In December 2012, Belgium's Constitutional Court rejected appeals for the ban to be annulled, ruling that it did not violate human rights. Along similar lines, the European Court of Human Rights (ECHR) in its judgment in S.A.S v. France (No. 43835/11 2014) and subsequent judgments in Belcacemi and Oussar v. Belgium (No. 37798/13 2017) and Dakir v. Belgium (No. 4619/12 2017), held that the French and Belgian laws and decrees banning the wearing of clothing that fully or partially conceals the face in public places are not in breach of the European Convention on Human Rights.

Following the example set by France and Belgium, legislation has gone into effect in Austria (since October 2017), banning the niqab in public spaces. The rationale behind the ban was to protect Austrian values on the basis that the wearing of the niqab stands in the way of 'open communication', which is fundamental to an 'open society'. In May 2018, Denmark became the latest European country to pass legislation banning the wearing of the niqab in public places. The law came into force on 1st August 2018. Those violating

${ }^{1}$ Irene Zempi: Email irene.zempi@ntu.ac.uk, Twitter @DrIrene.Zempi 
the law risk a fine of 1,000 kroner ( $₹ 118)$ whilst repeat offenders could be fined up to 10,000 kroner. Other European countries have local bans on facecovering veils. In Italy, the north-western town of Novara is one of several local authorities to have already brought in rules to deter public use of the niqab whilst in the Lombardy region of Italy, a niqab ban came into effect in January 2016. A parliamentary commission has approved a draft law banning women from wearing niqabs in public whilst an old anti-terrorist law against concealing the face for security reasons has already been used by some local Italian authorities to fine Muslim women who wear the niqab. Some mayors from the anti-immigrant Northern League have also banned the use of burkinis. In Spain, the city of Barcelona has implemented a veil ban in some public spaces such as municipal offices, public markets and libraries, whilst at least two smaller towns in Catalonia, the north-eastern region that includes Barcelona, have already imposed veil bans. However, a veil ban in the town of Lleida was overturned by Spain's Supreme Court in February 2013 on the basis that it is an infringement of religious liberties.

The Dutch government has introduced a partial ban on face covering in public in November 2016. The ban reflected the influence of far-right Party for Freedom (PVV), led by Geert Wilders, who argues for banning the wearing of the niqab in public in the Netherlands. In the 2017 legislative elections, PVV called for the total 'de-Islamification' of the country. Under PVV proposals, mosques and Muslim schools will be closed; the borders will be shut down with a blanket ban on migrants from Muslim countries; the wearing of the niqab in public will be illegal and the Koran will be banned. Although there are no national law restricting the wearing of veils in Germany, there have been proposals for banning the niqab. In 2016, Chancellor Angela Merkel stated the wearing of the niqab should be prohibited in Germany "wherever it is legally possible" (BBC 2017). The British government has not entertained a veil ban so far. However, although the UK does not have any legislative prohibitions in place, there are calls for such legislation to be introduced. In 2010, the Conservative MP Philip Hollobone sought to introduce a Private Members' Bill, entitled the Face Coverings Regulations Bill, which would make it illegal for people to cover their faces in public. The Bill, which received its second reading in the House of Commons in December 2011, was rejected. The British National Party and the UK Independence Party consistently support a veil ban in their manifestos, whilst extreme protest movements such as the English Defence League have staged a number of violent anti-Muslim protests against Islamic symbols namely, mosques and the wearing of the niqab. Former UKIP leader Nigel Farage said that full veils are a symbol of an "increasingly divided Britain", that they oppress women, and are a potential security threat. In August 2018, former foreign secretary Boris Johnson compared Muslim women in niqab to "letterboxes" and "bank robbers" (Elgot 2018). Prime Minister Theresa May has urged Johnson to apologise for these

${ }^{1}$ Irene Zempi: Email irene.zempi@ntu.ac.uk, Twitter @DrIrene.Zempi 
comments after he defied an order to do so by Tory chiefs. A YouGov (2016) poll showed that 57 per cent of the British public support a veil ban in the UK.

\section{The research study}

The aim of this study was to examine the lived experiences of Muslim women who wear the niqab in the UK. Specifically, this was a qualitative study that included 60 in-depth interviews and 20 focus groups with niqab-wearing women in Leicester between 2011 and 2012. All the participants wore fulllength jilbabs (long robe) accompanied with hijabs (headscarves) and niqabs (face veils) at the time of conducting the study. The interview guide included questions on veiled Muslim women's reasons for wearing the niqab, their experiences of hate crime in public as well as their views on the veil ban. The framework which was used to guide the research design and data collection was Grounded Theory (Glaser and Strauss, 1967), where themes were allowed to emerge from the data. Participation in the study was voluntary. Participants' real names have been replaced by pseudonyms in order to maintain their anonymity.

Prospective participants were identified through local Muslim organisations including mosques, Muslim schools and Islamic centres, local Muslim university student societies and Muslim women's groups. Participants unaffiliated to any local Muslim organisations or groups were also recruited through snowball sampling. At the time of the fieldwork, the women who took part in the study were residents living in Leicester. Leicester has a large and rapidly expanding population of Muslims and niqab-wearing women, making it an ideal site in which to conduct this study. However, it is important to note the limitations of this methodological approach. Despite the rich empirical data, the fact that all the participants were from the same city means that it is not possible to generalise the findings. A further limitation of the study is the fact that all the participants were identified through local organisations and snowball sampling. This means that the views of veiled Muslim women who were not affiliated to local Muslim organisations or to other participants were not included in this study. Therefore, the sample does not cover the full spectrum of views and experiences that might be held by veiled Muslim women and as a result, the study is not representative of the experiences and views of all veiled Muslim women. Collectively, these limitations do not undermine the significance of the study but it is clear that future research should explore them in more depth.

\section{Critical Race Feminism}

Critical Race Feminism provides an ideal framework with which to analyse veiled Muslim women's perceptions of the veil ban, and how these perceptions are influenced by the multiple sources of oppression at work in their lives. Critical Race Feminism emphasises the legal status of women of

${ }^{1}$ Irene Zempi: Email irene.zempi@ntu.ac.uk, Twitter @DrIrene.Zempi 
colour around the world and notes the 'multiple consciousness' that women of colour may feel - an awareness of simultaneously facing oppression as a result of both their race/ethnicity and gender (Matsuda 1992). Wing and Smith (2006) argue that women of colour may consciously or unconsciously face multiple and simultaneous discrimination, not only because of their race/ethnicity and gender, but also because of their religion, class, disability, sexual orientation, nationality, language, age, body shape and size, marital status, parental status, and/or political ideology. A discussion of the veil ban illustrates the multiplicative and intersectional nature of the potential discriminations involved. As such, Critical Race Feminism provides a perspective to lift the veil of ignorance and misunderstanding concerning the veil ban and its effects on Muslim women.

Additionally, Critical Race Feminism proves to be a particularly valuable tool in examining the experiences of marginalised, minority group women. Droogsma (2007) states that including women's experiences proves particularly important in examinations of women in marginalised groups in order to avoid perpetuating dominant, stereotypical understandings of their experiences. Indeed, in the age of the War on Terror veiled Muslim women have been essentialised as terrorists or terrorist sympathisers (Wing and Smith 2006). Also, the wearing of the niqab signifies the oppression of Muslim women. In other words, the veiled body is over-determined as an 'oppressed' body whereby gender oppression is the sole dimension through which veiled Muslim women are seen (Al-Saji 2010). While dominant perceptions of wearing the veil assume that it functions to oppress Muslim women, women who wear it might possess qualitatively different understandings of how veiling actually functions in their lives (Droogsma 2007). In order to 'liberate' Muslim women, some countries have banned the wearing of the niqab in public. As Howard (2014) points out, what is lacking in political, media and public debates are the voices of women who actually wear the niqab. The insider perspectives of veiled Muslim women are not taken into account by those governments banning it. As such, veiled Muslim women are denied a voice in the law-making process. Brems et al. $(2012,2)$ note that it was striking to find in the political debates about the veil ban, "a complete lack of knowledge about women who wear the face veil" and "the complete absence of the voices of women wearing the face veil". This is also the case in the Netherlands and France (Bouteldja 2013, Moors 2009).

To complicate matters further, a consideration of the opinions of the women themselves is absent in the deliberations and discussions on proposals for legislation or in media reports (Howard 2014). This creates false knowledge for veiled Muslim women. Even in cases where women insist on their choice to wear it, their claims are interpreted as an example of 'false consciousness'. This is evident in the reasoning of the Belgian Constitutional Court: "Even if

${ }^{1}$ Irene Zempi: Email irene.zempi@ntu.ac.uk, Twitter @DrIrene.Zempi 
the wearing of a face veil results from a well considered choice by the woman, still gender equality, which the legislator rightly considers a fundamental value of democratic society, justifies the State resisting in the public sphere the expression of a religious conviction by behaviour that cannot be reconciled with that principle of equality between a man and a woman" (Belgian Constitutional Court, judgment 145/2012 of 6 December 2012, para. B.23). In this regard, Muslim women are denied the possibility to be active agents capable of rational choices because they are considered to be 'blind' to their own oppression. To this end, veiled Muslim women become 'silent symbols, where national and international politics are played out on their bodies, heads, and minds' (Wing and Smith 2006, 747).

The racialisation of veiled Muslim women does more than represent them as passive victims, it also enforces a space that imaginatively and often practically excludes their multiple subjectivities, reducing the complex meanings and enactments of their veiling to Islamic oppression (AI-Saji 2010). Odeh (1993) explores the question of the veil from the complicated perspective of an Arab feminist, who both rejects the veil as a personal choice but also recognises its empowering effect on Arab women. Odeh (1993) notes that her discussion is limited to the veil as it plays itself out in an Arab context (and therefore it might not apply to non-Arab Muslim countries); however, a key argument made in this discussion is that the veiled body is not monolithic. With respect to whether the veil is a form of empowerment or disempowerment, Odeh $(1993,35)$ states that 'Of course, a veiled woman is not necessarily either this or that. She could shift from one position to the other. At times colourful, other times bland, seductive and prudish, public and private. A veiled woman's subjectivity appears to be much more complicated than the simple word of the veil can possibly convey." Although the rhetoric of the veil seeks to construct a monolithic female body, the community of veiled Muslim women shows that there is not such a single construction; rather, it demonstrates a multiplicity of identities.

Brems (2014) highlights the importance of the insider view, that is, taking into account the lived experiences of the people who are affected by a rule, rather than building on unchecked assumptions. Within the context of the veil ban, this entails including veiled Muslim women's personal views and experiences. This is understood as a means to realise the emancipatory goal of feminist research; it is also understood as a means to understand the reality of oppression that outsiders, who are part of the oppressive system, cannot otherwise understand (Brems 2015). Since Critical Race Feminism is centrally concerned with 'demarginalising' the views of Muslim women and girls themselves, and not just reporting what others (typically males) think about them, it is important to hear the Muslim female voices on this issue. Most of the discussions regarding the veil debate and legislation banning the niqab

${ }^{1}$ Irene Zempi: Email irene.zempi@ntu.ac.uk, Twitter @DrIrene.Zempi 
are perpetuated by male voices, and the girls and women who were affected are hardly ever allowed to voice their experiences, views and feelings (Wing and Smith 2006). To this end, insider experiences of marginalised and/or oppressed minorities such as women who wear the niqab are of paramount importance when considering such legislation.

\section{Previous Research}

Brems et al. (2011) conducted semi-structured, in-depth interviews and two focus group interviews with 27 veiled Muslim women in Belgium. Some participants were interviewed before and some were interviewed after the veil ban in Belgium. All the participants reported that it was their autonomous choice to wear the niqab (Brems et al. 2011). They experienced the veil ban as a denial of their autonomy and anti-emancipatory. Participants in Brems et al.'s (2011) study continued to wear it despite the ban, yet avoided going out. A strong sense of danger was prevalent amongst participants whilst they reported that verbal abuse and occasional physical abuse was a common aspect of their lives (Brems et al. 2011). In some cases, they reported being refused to be served, for example at the hospital, school or the market because of their niqab.

Drawing on research with 35 veiled Muslim women in France, Bouteldja (2013) examined the effects of the French veil ban on their lives. Participants in this study emphasised their personal religious commitment to continue wearing the niqab (Bouteldja 2013). In other words, the implementation of the French veil ban had not stopped women from wearing it. All of the participants argued that the law had significant negative effects on their lives, and that it had neither empowered nor liberated them (Bouteldja 2013). They compared their lives in France after the veil ban to being held in a prison. Some participants continued to wear the niqab in France after the implementation of the ban but argued that the fear of being stopped by the police or abused by members of the public prevented them from leaving their house (Bouteldja 2013). It is important to point out that no participants reported experiencing empowerment or liberation as the law was intended; rather, all the participants reported socialising less, and reducing their outdoors activities to the strictest minimum (Bouteldja 2013). However, the constraints on their movements and lack of physical exercise had taken a toll on the physical and mental health of many participants. They reported suffering depression and anxiety attacks when leaving their house, and an overall deterioration of their health (Bouteldja 2013). To complicate matters further, the veil ban had also affected their family life, increasing their dependence on their partners, relatives and friends, and negatively affecting their relationship with their children.

It is important to note the racist and Islamophobic lens through which Islam and veiled Muslim women are seen, historically and in a contemporary context. Moors (2011) observes that the association between the niqab and

${ }^{1}$ Irene Zempi: Email irene.zempi@ntu.ac.uk, Twitter @DrIrene.Zempi 
gender inequality can be traced back to colonial discourses that considered veiling as a sign of gender oppression. Referring to the French context, Al-Saji (2010) argues that the veil ban is a form of cultural racism that hides itself under the guise of anti-sexist and feminist liberation. In other words, the racism that structures the perception of the veil as a form of gender oppression is manifested as anti-sexist and feminist concern for the liberation of Muslim women (Al-Saji 2010). From this perspective, what is differentially visible is not skin colour as such, but culture defined largely through the perceived presence of gender oppression embodied in veiling practices. Brems (2015) observes that in the current Islamophobic context, the veil ban legimitises and promotes Islamophobia. The media, political and public debates surrounding the veil ban promote negative stereotypes that equate Islam with gender inequality, fundamentalism, terrorism and backwardness.

Accordingly, research in Belgium (Brems et al. 2012) and France (Bouteldja 2013) shows that the veil ban has emboldened ordinary citizens to show aggressive behaviour towards veiled Muslim women. To illustrate this, participants in Bouteldja's (2013) study reported that verbal abuse and harassment by members of the public was a common experience for women who continued to wear the niqab after the veil ban was introduced in France. Participants reported physical assaults, including having their veil pulled off, being violently pushed, and being spat on (Bouteldja 2013). Many participants described incidents in which members of the public abusively confronted them, in some cases using their mobile phones to report them to the police or situations where angry groups gathered around them (Bouteldja 2013). Participants felt that the law has given the green light for people to be abusive and discriminate against them. When discriminated against or abused, participants felt there was no legal recourse with which to seek justice (Bouteldja 2013). However, it is important to note the possibility of appeals in such cases, beyond the feelings of those who feel discriminated against.

\section{Findings}

The analysis is structured thematically, drawing on the following themes: (1) Veil ban as a form of gender oppression, racism and Islamophobia (2) Veil ban as a form of imprisonment and (3) Ripple effects of the French veil ban in the UK. The process of developing and organising these themes included reading the transcripts and generating codes across the entire data set, collating data relevant to each code. The author then examined the codes and collated data to identify candidate themes. Candidate themes were reviewed and then, refined themes were linked back to the research questions namely, veiled Muslim women's reasons for wearing the niqab, their experiences of hate crime in public and their views on the veil ban.

\section{Veil ban as a form of gender oppression, racism and Islamophobia}

${ }^{1}$ Irene Zempi: Email irene.zempi@ntu.ac.uk, Twitter @DrIrene.Zempi 
Participants rejected the idea of Muslim women being forced to wear the niqab, and argued that actually, it was the law banning the niqab that oppressed Muslim women.

What form of liberation is that for Muslim women? They are not liberating us, they are oppressing us. (Zohra)

I am not oppressed, my mum and dad didn't really want me to wear it. I didn't really discuss it with them I just told them "I'm just letting you know kind of thing' [...] Not to say that there isn't girls who are being forced to wear the veil because there is, but that would be a very small minority of women. (Parveen)

People think it must be the man forcing the woman to wear it because, you know, all us Muslim women are really stupid, we just do what the men tell us to do (laughs). People have such a low opinion of Muslim women and I think "hang on a minute, if you were a real feminist, you would respect the way that a woman dresses, isn't that what liberating women is all about?" (Talibah)

As indicated in the quotes above, participants rejected notions of being forced to wear the niqab and suggested that the veil ban oppressed rather than liberated Muslim women. In this journal, Zempi (2016) has discussed the reasons why veiled Muslim women adopt the niqab. In short, Zempi (2016) argued that the wearing of the niqab emerges as a personal choice, an expression of religious piety, public modesty and belonging to the worldwide, transnational Muslim community, the 'ummah'. Similarly, research with veiled Muslim women in Belgium (Brems et al. 2012), the Netherlands (Moors 2009), Denmark (Warburg 2009 as cited in Brems 2014) and France (Bouteldja 2011) shows that they wear it out of a personal and autonomous choice. Evidence also demonstrates that the veil ban does not help the emancipation of veiled Muslim women and even works against it (Brems et al. 2012). Participants in the present study argued that the veil ban was a paternalistic, sexist and misogynistic law, which promoted the objectification of veiled Muslim women, as the following quotes demonstrate.

They are dictating to women what they can and can't wear, which is completely wrong. It is against human rights. This is men dictating to women what they can wear, that's all it is. (Aisha)

It's a man-made image, they want to look at our bodies. For me it's a sexist issue because they're saying "we want women all to be sexual objects". (Iffat)

French politicians want to see this 'modernised' western world and they just don't want this image [of the niqab] to be there because

${ }^{1}$ Irene Zempi: Email irene.zempi@ntu.ac.uk, Twitter @DrIrene.Zempi 
that image is not a symbol of the sexual exploitation of women. (Kamil)

I think the idea that you are telling people "you have to look a certain way" is wrong. Why should it be that a woman has to show her face to every Tom, Dick, and Harry? Women should have the right to make a decision about what they choose to wear. (Latifah)

Furthermore participants described the veil ban as a form of racism and Islamophobia, as the following quotes indicate.

For me it is a racist law. They don't have any right to impose restrictions on a religious practice. (Tashia)

This is Islamophobia. They banned the niqab but it is only worn by one per cent of the Muslim population in France. These women are not terrorists. It is because of Islamophobia that they banned it. (Aisha)

The French veil ban is a form of Islamophobia. We are attacked verbally and physically and through the ideology that politicians promote. (Hadia)

\section{$\underline{\text { Veil ban as a form of imprisonment }}$}

In line with interpreting the veil ban as a sexist, oppressive and misogynistic law, participants also argued that the veil ban had resulted in 'house arrest' for veiled Muslim women in France. From this perspective, the veil ban forces women to stay in the house as they do not want to remove their niqab in public. As such, the veil ban becomes a form of 'imprisonment' for veiled Muslim women who do not wish to remove their niqab in public.

This is what happens, most of them stay in the house. They are in house arrest, the house is like a prison for them. The French government has made them prisoners in their own house. (Amtullah)

Our Muslim sisters are made to feel prisoners in their own house. Those people who made the laws, they should be imprisoned and they should be made to feel what it's like to be totally unwanted, they should be made to feel like that. (Tahirah)

This sense of 'house arrest' was also highlighted by one of the participants, Alia who had moved from France to the UK because of the veil ban in France. Similarly, other participants who spoke to their friends in France noted that they had not left the house since the veil ban came into effect in April 2011. 
When I was in Paris I couldn't go outside the house, I couldn't go to the park with my children, I couldn't share any activities with them. That was not a life for me to stay there. (Alia)

My friends in France tell me that they don't go out. They continue to wear it because they don't want to take it off. For them it feels like stripping off if they don't wear it, so they stay inside the house and they don't go out. The law started in April 2011 and one of my friends told me on the phone that she has not been out of the house since then. (Kamil)

Participants reported feeling sad, angry and upset with the negative implications of the veil ban for their Muslim sisters in France.

I feel for sisters in France. It is their right to wear the veil. Sisters in France should not be subjugated to something they don't want to do. (Hallemah)

I feel sorry for the sisters in that every person has their own human rights. They should be free to wear what they like. (Farhat)

Ripple effects of the French veil ban in the UK

Throughout individual and focus group interviews in the present study, participants pointed out that the veil ban promoted hostility against veiled Muslim women not only in those countries where it was illegal to wear it but also in the UK on the basis that it promoted perceptions of veiled Muslim women as 'criminals'. As such, participants felt that the veil ban in France and Belgium had given ammunition to people in other countries such as the UK to attack veiled Muslim women. To this end, participants reported that they had experienced a rise in verbal and physical attacks in the UK because of the veil ban in France.

Hostility has increased here because of the French veil ban. France is a European country, isn't it? There is so much about it in the media about the niqab and it's all negative. There is a man who lives in my neighbourhood, and he said to me "you are evil people, the veil should be banned, it's banned in France" and once he called me a 'witch'. It's terrible really. I have to put up with it, there is nothing I can do. (Rayhana)

I've been wearing the veil for approximately 27 years now. There is a ripple effect in the UK of what they are doing in France. They are making society be prepared to attack women in veil because of the way the media and certain politicians portray it. If it is 
acceptable for politicians to attack the veil, then they encourage society to be hostile towards veiled Muslim women. (Anisa)

Initially when it started in France and then Belgium and here the UKIP party started it "ban the veil", that's when they were having debates on the radio and for a time it was quite tensed. I felt that from that moment on, people felt that they had more rights to say things to us than prior to the veil ban in France. I feel that people that would not have spoken up before suddenly said "no, ban the veil, you don't have to wear it, British have to be British". What is being British? You tell me what is being British; we work, we pay our taxes, we look after our neighbours, we just dress differently, what's wrong with that? (Khadija)

Participants also pointed out that the veil ban in France had led to debates about introducing the veil ban in the UK, which made them feel insecure about their future in the UK.

There is a debate in Britain because France is our nearest neighbour and is very similar culture-wise, so people feel if it can be done in France, which is our next door neighbour, the next step is to ban it in Britain. (Latifah)

British people are like "oh, yes let's get rid of it, let's ban it now" because there are other countries that are doing it, it's like following the trend kind of thing. (Arifa)

I read blogs about banning the niqab and most comments are like "They should ban it here as well". (Jabeen)

The issue of the niqab being banned in the UK was also discussed in a focus group interview at an Islamic centre, as indicated in the comments below.

Participant A: The law affects Muslims more than other religious communities although the French government say "oh it's not against Islam" they try make it generic but in practice they are attacking the veil, they are attacking Islam.

Participant B: I think it's disgusting. It's somebody's freedom, it's somebody's choice, the way they dress, how can they take that away?

Participant C: I've been following that very carefully because I want to know what's going to happen here. I know that Holland, Denmark, Germany, Spain, Italy they are all watching what France is doing, I think Holland was thinking of it and then they just put it in the back burner. I'll tell you what concerns me, because I 
always say to myself "it's not going to happen here", but the Muslim population in France is the biggest in Europe, that scares me. It has heightened Islamophobia in this country [UK]. British people thought "we will put up with it", they never thought to ban it before. There's a few good years that l'd go to town and l'd hear nothing, but it started up again, somebody did pull my veil off recently, I fear for myself and my children.

Participants shared their views on how they would cope with banning the niqab in the UK. The majority of participants argued that they would move to another country where it would be possible to practise their religion without the fear of 'state persecution'.

If there was a ban in this country, I would move to another country, I really would. (Sadiyyah)

I anticipate a ban on the niqab in this country at the cost of our religious rights. I speak to sisters and brothers and they would all immediately leave the country if the ban was introduced. I believe the niqab ban is pending in the UK. In Islamic circles it is never a question of "will they?" It is a question of when. We are all uncertain of our future as Muslims in the UK. It does not look like it is going to be easy to practise Islam in the UK in the coming years. (Zainab)

If the law came here, we would leave the country. Islam teaches you that if you are in a country where it is hard for you to practise your faith then there is no reason for you to stay there. (Rayhana)

If the UK introduced a veil ban, I would leave the country in the first instance and go wherever I can to take refuge, whichever country allows me to practise my faith. I would first support your research about Muslim women and then I would leave the country. I can't take the veil off, there's no way. They can kill this [showing her head] but they can't take this off [showing niqab]. (Aisha)

The issue of how women would cope with a veil ban in the UK was also discussed in a focus group interview at a mosque, as indicated in the comments below.

Participant A: I wouldn't go out of the house, I wouldn't take my veil off. I don't care what would happen. It's like house arrest without going through the court, isn't it?

Participant B: Personally, I would move to another country. We are made to believe that in order to practise our religion we need to move. They think "let's force them out, let's push them into such a

${ }^{1}$ Irene Zempi: Email irene.zempi@ntu.ac.uk, Twitter @DrIrene.Zempi 
position where Muslims feel they can't practise their religion". I have heard lots of families saying they have thought of moving to another country, I'm not saying they are all packing up their bags and moving but the thought is there whereas the thought wasn't there before the French ban.

Participant C: But some women can't move to another country? You know, there is this guy who is paying their fines in France, he is building up women's confidence to keep the veil on. Women in France have been in house arrest, they can't go to the doctors, they can't go on public transport, at least there is someone who has guts and the money to pay for the fines.

In line with these comments, veiled Muslim women in Moors' (2011) study argued that they were considering moving from the Netherlands to a more Islam-friendly country because of the increased hostility that they suffered as a result of political debates on banning the niqab in the Netherlands. Participants reported incidents of being threatened or insulted, cars trying to hit them, people throwing things at them or trying to pull off their veils (Moors 2011). They also argued that perpetrators appeared confident or entitled because of politicians' support for banning the niqab in the Netherlands (Moors 2011).

\section{Discussion}

In the current climate, the wearing of the niqab has become the focus of political, media and public debates in which veiled Muslim women themselves do not have a voice. Equally worryingly, the voices of veiled Muslim women are markedly absent in the law-making process in those countries, which have banned the wearing of the niqab in public (Al-Saji 2010). To complicate matters further, the veil ban maintains this voicelessness through promoting false assumptions about the niqab (Brems 2012). Throughout political, media and societal debates about the niqab, it is commonly assumed that Muslim women are forced to wear it. By implication, it is assumed that the veil ban liberates these women from oppression. However, as the preceding discussion demonstrates, this assumption is false.

Critical Race Feminism offers the opportunity to examine the interpretations veiled Muslim women have of the veil ban while recognising the complex forces that shape their experiences and, thus, their insights. Instead of focusing on the discourses that attempt to essentialise veiled Muslim women, Critical Race Feminism focuses on the neglected resource of women's experiences, leading to a clearer understanding of veiled Muslim women's perceptions of the veil ban. Correspondingly, participants in the present study unanimously rejected the veil ban. They argued that it was a sexist,

${ }^{1}$ Irene Zempi: Email irene.zempi@ntu.ac.uk, Twitter @DrIrene.Zempi 
oppressive and misogynistic law. Similarly, empirical research amongst women who wear the niqab in Belgium, Netherlands, Denmark and France shows that the assumption that Muslim women are forced to wear it is false (Bouteldja 2011, Brems et al. 2012, Moors 2009, Warburg 2009 as cited in Brems 2014).

As Brems (2015) points out, the veil ban cannot be considered emancipatory as it denies women's autonomy rather than empowering it. Indeed, participants in the present study argued that rather than liberating them, the veil ban oppresses veiled Muslim women and forces them into 'house arrest'. Bouteldja (2013) found that the French veil ban had adverse effects on women's personal and family lives. The findings revealed that participants continued to wear it despite the ban, but they avoided leaving the house. They described living 'in a jail' since the ban's enforcement (Bouteldja 2013). This also means that their movements had been severely restricted by the veil ban. Some participants stated that they started wearing the niqab after the implementation of the law in order to show their disagreement with the French veil ban (Bouteldja 2013). However, some women did remove their niqab in order to comply with the law, out of fear of being arrested by the police or being assaulted by members of the public. None of those participants who removed the niqab framed the decision in terms of a positive liberatory release; rather, they reported that they were socialising less because they did not feel comfortable leaving their homes with their faces uncovered (Bouteldja 2013).

Yet the veil debate has not translated into a sophisticated understanding of the ways in which veiled Muslim women's lived experiences are mediated by factors such as gender, age, race, ethnicity, education, socio-economic status and space, to name but some (Chakraborti and Zempi 2013). Rather, the veil ban marginalises Muslim women further, excluding them from access to education, employment, health care, public transport and of course, public space (Moors 2011). It is a form of discrimination on grounds of religion as well as gender. It dehumanises women and leads to self-exclusion. Denmark is the latest country to jump on the 'veil ban bandwagon' with France, Belgium and Austria imposing national bans on the wearing of the niqab in public. However, if these governments really want to liberate women, this should be achieved through education, access to justice and economic opportunity rather than through oppression (Van Gulik 2009).

\section{Conclusion}

Within the framework of Critical Race Feminism, this paper explored the implications of legislation banning the wearing of the niqab in public from the standpoints of veiled Muslim women that are currently overlooked by dominant conceptions. Drawing on individual and focus group interviews with

${ }^{1}$ Irene Zempi: Email irene.zempi@ntu.ac.uk, Twitter @DrIrene.Zempi 
Muslim women who wear the niqab in the UK, this article explored their views on the veil ban. It is of paramount importance that their views are known, especially on an issue that disproportionately affects them and their community (Wing and Smith 2006). Participants argued that the veil ban is a sexist and oppressive law, which forces veiled Muslim women to house arrest', excluding them from public spaces in those countries where the ban has been implemented. Participants also noted that the veil ban promotes Islamophobic and racist attitudes in other countries where it is still legal to wear it (such as the UK), thus increasing the risk of veiled Muslim women being attacked when seen in public. In other words, the veil ban was perceived as a form of racism and Islamophobia, which increases hostility towards veiled Muslim women in the UK. A couple of participants had moved to the UK from France because they could not practise their religion any longer there as a result of the veil ban. However, although they could wear the niqab in the UK, they were not safe because of the risk of being attacked when they were seen in public. Overall, the findings show that the veil ban does not serve its stated purpose; rather, it is a violation of human rights. Heated and controversial debates about the wearing of the niqab in the UK coupled with adoption of local or national bans in other European countries have increased the risk of women being attacked as the criminalisation of the niqab provides justification for these attacks. To this end, veiled Muslim women are caught in the whirlwind of debates and laws, which trigger negative reactions against them when they are seen in public. Ultimately, banning the niqab is as paternalistic and oppressive of Muslim women as forcing them to wear it. 


\section{References}

Al-Saji, A. 2010. "The Racialisation of Muslim Veils: A Philosophical Analysis." Philosophy and Social Criticism 36 (8): 875-902.

BBC 2017. "Angela Merkel endorses burka ban 'wherever legally possible." Accessed 1 August 2018. https://www.bbc.co.uk/news/world-europe$\underline{38226081}$

Bouteldja, N. 2011. Unveiling the Truth. Why 32 Muslim Women Wear the Full-face Veil in France. New York: Open Society Foundations.

Bouteldja, N. 2013. After the Ban: the Experiences of 35 Women of the FullFace Veil in France. York: Open Society Foundations.

Brems, E. 2001. Human Rights: Universality and Diversity. Hague: Martinus Nijhoff.

Brems, E. 2014. The Experiences of Face Veil Wearers in Europe and the Law. Cambridge: Cambridge University Press.

Brems, E. 2015. "Equality problems in multicultural human rights claims: the example of the Belgian "burqa ban." Accessed 1 June 2018. http://sim.rebo.uu.nl/wp-content/uploads/2015/04/Brems Equality-problemsin-multicultural-human-rights-claims.pdf

Brems, E., Janssens, Y., Lecoyer, K., Ouald Chaib, S. and Vandersteen, V. 2012. "Wearing the Face Veil in Belgium; Views and Experiences of 27 Women Living in Belgium concerning the Islamic Full Face Veil and the Belgian Ban on Face Covering." Accessed 15 July 2018. www.ugent.be/re/publiekrecht/en/research/human-rights/faceveil.pdf

Chakraborti, N. and Zempi, I. 2013. "Criminalising Oppression or Reinforcing Oppression? The Implications of Veil Ban Laws for Muslim Women in the West." Northern Ireland Legal Quarterly 64 (1): 63-74.

Chrisafis, A. 2016. "French mayors refuse to lift burkini ban despite court ruling." Accessed 1 July 2018. https://www.theguardian.com/world/2016/aug/28/french-mayors-burkini-bancourt-ruling

Delphy, C. 2004. "'Une affaire française." in Le foulard islamique en questions, edited by C. Nordmann, 64-71. Paris: Editions Amsterdam.

Droogsma, R. A. 2007. "Redefining Hijab: American Muslim women's standpoints on veiling". Journal of Applied Communication Research 35 (3): 294-319.

${ }^{1}$ Irene Zempi: Email irene.zempi@ntu.ac.uk, Twitter @DrIrene.Zempi 
Elgot, J. 2018. "Boris Johnson accused of 'dog-whistle' Islamophobia over burqa comments." Accessed 15 July 2018. https://www.theguardian.com/politics/2018/aug/06/boris-johnsons-burqaremarks-fan-flames-of-islamophobia-says-mp?CMP=share_btn_tw

Glaser, B.G. and Strauss, A. L. 1967. The Discovery of Grounded Theory: Strategies for Qualitative Research. London: Sage.

Grillo, R. and Shah, P. 2012. Reasons to Ban? The Anti-Burqa Movement in Western Europe. Göttingen: Max Planck Institute.

Hennink, M., Hutter, I. and Bailey, A. 2011. Qualitative Research Methods. London: Sage.

Howard, E. 2014. "Islamic veil bans: the gender equality justification and empirical evidence." In The Experiences of Face Veil Wearers in Europe and the Law, edited by E. Brems, 206-217. Cambridge: Cambridge University Press.

Matsuda, M. J. 1992. "When the First Quail Calls: Multiple Consciousness as Jurisprudential Method" 14 Women's Rts. L. Rep 297: 289-299.

Moors, A., 2009. "The Dutch and the Face-Veil: The Politics of Discomfort." Social Anthropology 17 (4): 393-409.

Moors, A., 2011. "Minister Donner as Mufti: New Developments in the Dutch "Burqa" Debates." Accessed 1 July 2018. http://religionresearch.org/martijn/2011/09/21/ministerdonner-as-mufti-newdevelopments-in-the-dutch-\%E2\%80\%98burqa-de bates\%E2\%80\%99/

Odeh, L. A. 1993. "Post-colonial feminism and the veil: Thinking the difference". Feminist Review 43 (1): 26-37.

Van Gulik, G. 2009. "Headscarves: the wrong battle". Accessed 1 June 2018. www.hrw.org/en/news/ 2009/03/14/headscarves-wrong-battle.

Wing, A. K., and Smith, M. N. 2005. "Critical race feminism lifts the veil: Muslim women, France, and the headscarf ban." UC Davis Law Review 39: 743-785.

YOUGOV 2016. "Ban the burka, says majority of the British public." Accessed 5 July 2018. https://yougov.co.uk/news/2016/08/31/majority-publicbacks-burka-ban/

Zempi, I. 2016. "It's a part of me, I feel naked without it": choice, agency and identity for Muslim women who wear the niqab." Ethnic and Racial Studies 39 (10): 1738-1754. 